\title{
PROFIL KOMPETENSI PROFESI SISTEM INFORMASI BERBASIS KNOWLEDGE MANAGEMENT
}

\author{
Sudaryono ${ }^{1}$ \\ Henderi $^{2}$ \\ Ira Tyas Ningrum ${ }^{3}$ \\ e-mail:sudaryono2@yahoo.com,henderi@pribadiraharja.com, \\ ira_tyas@pribadiraharja.com,
}

Diterima: 15 Juli 2011/ Disetujui : 20 Agustus 2011

\begin{abstract}
In the era of knowledge management, has been a belief that the organization is capable of capturing and making use of knowledge hidden in every human resources it has to win the competition. Knowledge has become a more important economic resource of raw materials or money. Knowledge management emerged as the new mantra of modern organizational management in the face of competition in an increasingly competitive business environment. Similarly, the profile of professional competence of the information system should be developed based on knowledge management. Various efforts and research have been conducted to develop information systems professional competence profile. On the other hand, effort and research into competency-based human resources is also growing rapidly. This paper attempts to combine two things that are in two worlds intersect, namely the world of management information systems and knowledge-based competence is still a preliminary study and still needs further research.
\end{abstract}

Keywords: Knowledge management, information systems profession, human resources, competencies.

\section{ABSTRAKSI}

Pada era knowledge management,telah menjadi kepercayaan bahwa organisasi yang mampu menangkap dan memanfaatkan berbagai pengetahuan yang terkandung di dalam diri setiap Sumber daya manusia yang dimilikinya akan memenangkan persaingan.

1. Dosen Jurusan Sistem Komputer, STMIK Raharja

J1. Jend Sudirman No. 40 Modern Cikokol-Tangerang Telp. 5529692

2. Dosen Jurusan Teknik Informatika, STMIK Raharja

J1. Jend Sudirman No. 40 Modern Cikokol-Tangerang Telp. 5529692

3. Mahasiswa Jurusan Sistem Informasi, STMIK Raharja

J1. Jend Sudirman No. 40 Modern Cikokol-Tangerang Telp. 5529692

Vol.5 No.1 - September 2011 
Knowledge telah menjadi sumberdaya ekonomi yang lebih penting dari bahan baku atau uang. Knowledge management muncul sebagai mantera baru manajemen organisasi modern dalam menghadapi persaingan di lingkungan bisnis yang makin kompetitif. Demikian pula dengan profil kompetensi profesi sistem informasi harus dikembangkan berdasarkan knowledge management. Berbagai upaya dan riset telah dilakukan untuk menyusun profil kompetensi profesi sistem informasi. Di pihak lain, upaya dan riset mengenai sumber daya manusia berbasis kompetensi juga berkembang dengan pesat. Tulisan ini mencoba untuk memadukan dua hal yang berada di dua dunia yang saling bersinggungan, yaitu dunia sistem informasi dan dunia manajemen pengetahuan yang berbasis kompetensi yang masih merupakan studi awal dan masih memerlukan penelitian lanjutan.

Kata kunci : Knowledge management, profesi sistem informasi, sumber daya manusia, kompetensi.

\section{PENDAHULUAN}

Pengetahuan telah menjadi sebuah senjata penting dalam memperoleh sustaining competitive advantage. Oleh karena itu, banyak organisasi mulai mengelola pengetahuan organisasi. Hal ini terjadi karena keunggulan kompetitif di abad ini dicirikan oleh "knowing how to do things", bukan sekedar memiliki akses tertentu pada sumber daya dan pasar. Pengetahuan juga sering disebut sebagai modal intelektual. Modal intelektual jauh lebih penting daripada tanah, tenaga kerja, dan modal financial. Pengetahuan memiliki nilai strategis, melebihi brand name dan asset fisik. Menurut Tapscott (1996), modal hanyalah fungsi dari pengetahuan. Melalui penggunaan yang sistematis, pengetahuan merupakan infinite economic goods yang dapat menghasilkan kenaikan returns. Namun pada kenyataannya di era global ini, mesin pembangkit kesejahteraan yang lain adalah ada dalam pekerjaan itu sendiri. Bentuknya bisa berupa: teknologi, inovasi, sains, know-how, kreativitas, dan sistem informasi. Sistem informasi telah menghadirkan media baru dalam penyebaran informasi, yaitu media digital. Informasi tidak lagi disusun atas atom-atom atau molekul-molekul - tetapi dalam bit-bit, telaah mempercepat dan mempermudah proses penyebarannya.

Paten dan berbagai tipe keahlian tidak akan membawa pada keunggulan kompetitif yang langgeng. Banyak dari pengetahuan yang kita miliki hanya merupakan sebuah transient competitive advantage dimana pesaing dengan mudah akan melakukan reverse engineer terhadap produk yang kita miliki, meng-copy best practices kita, dan mengembangkan teknologi yang parallel (bahkan lebih unggul) dengan teknologi yang kita miliki. Selain itu, 'know-how yang mengalir dari tacit knowledge individu merupakan asset organisasi yang sulit ditiru oleh pesaing. Dengan perkataan lain, pengetahuan yang bersifat tasit akan memperkokoh core competence organisasi. Oleh karenanya, manajemen pengetahuan telah menjadi "mantra baru" 
dari organisasi modern yang ingin menjadi pemenang dalam iklim kompetisi yang semakin hiperkompetitif dan menantang.

Manajemen pengetahuan tidak saja menjadi topik hangat untuk diperbincangkan, lebih dari itu, telah menjadi kunci utama pengembangan sumber daya manusia yang berkompeten dalam bisnis dan industri. Menurut Sharp (2003), ada tiga kekuatan utama yang menjadi sebuah kombinasi yang menarik bagi organisasi untuk mengimplementasikan manajemen pengetahuan dalam sistem informasi, yaitu: peningkatan dominasi pengetahuan sebagai basis bagi pencapaian efektivitas organisasi, kegagalan model financial dalam merepresentasikan dinamika pengetahuan, dan kegagalan teknologi informasi dalam mencapai manfaat yang substansial bagi organisasi. Hasil survei terbaru mengindikasikan bahwa implementasi manajemen pengetahuan telah berhasil meningkatkan efektivitas organisasi, memberikan value pada pelanggan, meningkatkan inovasi produk, meningkatkan kepuasan kerja karyawan, menekan retensi, dan meningkatkan keunggulan kompetitif di pasar.

Hasil survey Ernst \& Young for Business Innovation and Business Intelligence melaporkan inisiatif pengadopsian manajemen pengetahuan menghasilkan manfaat dalam peningkatan: pengambilan keputusan, respon kepada pelanggan, efisiensi staf dan operasi, inovasi, serta produk/jasa. Oleh karena itu, penerapan manajemen pengetahuan merupakan salah satu alternative terbaik untuk menghasilkan organisasi yang selalu siap untuk menjadi pemimpin pasar. Hal itu dapat dicapai dengan cara memperluas pasar yang sudah ada, bahkan menciptakan pasar baru. Konsekuensinya, organisasi (yang memiliki kemampuan untuk menciptakan pasar baru) tidak takut dan tidak perlu lagi berkompetisi. Dalam iklim bisnis yang turbulent, pengetahuan adalah 'pembeda' antara kesuksesan dan kegagalan. Para praktisi dan akademisi mulai tertarik untuk memperlakukan pengetahuan sebagai sumber daya organisasi yang signifikan, sebagai "the only true strategic asset" dalam menentukan profil profesi sistem informasi yang ingin dikembangkan.

Apakah orang yang menguasai secara teknis ilmu komputer atau teknologi informasi secara mendalam mampu memiliki kinerja yang baik dalam karirnya sebagai profesional di bidang sistem informasi? Apa sajakah kompetensi yang perlu dimiliki oleh para profesional di bidang sistem informasi supaya mampu berprestasi baik di bidangnya? Pengetahuan apa yang diperlukan untuk mengembangkan kompetensi yang harus dimiliki oleh seorang profesional dalam sistem informasi? Pertanyaan ini sangat menarik untuk disimak, dan bahkan dalam beberapa diskusi menimbulkan perdebatan yang sangat seru. Bila ditinjau lebih lanjut, berbagai upaya dan riset sudah dilakukan untuk menyusun profil kompetensi profesi sistem informasi yang 
berbasis manajement pengetahuan, antara lain oleh Feeny dan Wilcock, serta Marchand, et.al (Ward, 2002), juga oleh Bassellier dan Benbasat (Bassel, 2004).

Oleh karena itu sudah waktunya para ahli sistem informasi untuk memikirkan bagaimana mengembangkan profil profesi sistem informasi yang berbasis pada manajemen pengetahuan, agar dapat bersaing di era global. Tetapi dua studi ini belum memadukan penelitian dan temuan mereka dengan konsep pengembangan sumber daya manusia berbasis knowledge management. Padahal, di pihak lain, konsep pengembangan sumber daya manusia berbasis knowledge management menjadi semakin marak untuk diteliti dan dikembangkan dewasa ini. Tulisan ini mencoba untuk memadukan dua hal yang berbeda di dua dunia yang saling bersinggungan, yaitu dunia sistem informasi dan dunia sumber daya manusia berbasis knowledge management, dan masih merupakan studi awal yang perlu penelitian lanjutan.

\section{PERUMUSAN MASALAH}

1. Bagaimana mengembangkan knowledge management yang efektif dan efisien dalam sistem informasi?

2. Bagaimana menyusun profil kompetensi profesi sistem informasi berbasis knowledge management?

\section{STUDI LITERATUR DAN PEMBAHASAN}

\section{Mengapa Knowledge Management?}

Perspektif organisasi berbasis pengetahuan muncul dalam literature manajemen strategis. Perspektif ini dibangun berdasarkan dan perpanjangan dari teori resourcebased. Jadi, teori yang mampu menyediakan kerangka kerja teoritis yang jelas dan kohesif mengapa manajemen pengetahuan bisa menuntun pada tercapainya kinerja organisasi yang superior adalah teori resource-based.Para ahli strategi menyatakan bahwa strategic imperative dari organisasi harus langgeng, menghasilkan kinerja keuangan yang superior, dan percaya bahwa tujuan tersebut dapat dicapai melalui keunggulan kompetitif di marketplace. Keunggulan kompetitif yang langgeng muncul ketika sebuah organisasi mengembangkan core competency yang istimewa seperti manajemen pengetahuan. Prahalad dan Hamel (1990) mengobservasi bahwa sebuah core competency dasar akan menjadi sebuah core competency istimewa ketika core competency tersebut tidak saja dijalankan secara sangat bagus, tetapi juga secara relatif organisasi tersebut memiliki core competence yang lebih baik dari semua organisasi yang ada dalam industri. Kompetensi tersebut selanjutnya akan menjadi sumber keunggulan, dan jika penghalang organisasi lain untuk memiliki 
sumber daya tersebut muncul, maka sumber daya tersebut akan menjadi sumber daya jangka panjang dari economics rents (Spender, 2006).

Tidak mengherankan bila banyak akademisi menekankan bahwa keunggulan kompetitif dari organisasi sebaiknya berlandaskan pada sumber daya. Sumber daya tersebut dapat diinterpretasikan sebagai semua sumber daya material maupun immaterial dan aset intangible dari organisasi. Akan tetapi, tentu saja hanya asset yang benar-benar dimiliki oleh organisasi yang akan menjadi sumber daya. Apabila asset tersebut tidak dapat dikendalikan oleh organisasi, maka asset tersebut bukanlah sumber daya organisasi. Dilihat dari perspektif resource-based, organisasi dapat dipandang sebagai satu berkas dari sumber daya produktif. Diasumsikan bahwa, setiap organisasi memiliki sumber daya spesifik yang berbeda dengan sumber daya yang dimiliki oleh organisasi lain.

Sumber daya yang dimiliki harus mempunyai karakteristik: Pertama, sebuah sumber daya harus bernilai bagi organisasi. Artinya, sumber daya tersebut harus bermanfaat untuk organisasi. Kalau sebuah organisasi memiliki sumber daya spesifik yang tidak berkontribusi pada efisiensi dan efektivitas organisasi, maka sumber daya tersebut tidak bernilai pada organisasi. Agar bernilai, sebuah sumber daya normalnya harus dirasakan value-nya oleh pelanggan secara langsung maupun tidak langsung. Kedua, sumber daya harus bersifat langka. Implikasinya, sumber daya tersebut harus tidak mudah diakses secara mudah oleh kompetitor saat ini atau kompetitor potensial. Pemilik sumber daya tersebut hanya sejumlah kecil organisasi. Dengan demikian, organisasi tidak akan memperoleh keunggulan kompetitif dari sumber daya bernilai jika sumber daya tersebut dengan cepat dapat disediakan oleh organisasi untuk berkompetisi. Sumber daya yang benar-benar menempel (embedded) pada konteks organisasi biasanya merupakan sumber daya yang langka (Lang, 2003).

Ketiga, sumber daya harus bersifat sulit ditiru. Para pengajur resource-based view menekankan ketiga kondisi yang sesuai agar sumber daya bersifat sulit diimitasi: kondisi historis yang unik, ambiguitas kausal, dan kompleksitas sumber daya. Terakhir, keempat sumber daya harus sulit disubstitusi. Artinya, tidak ada kemungkinan yang sama, yaitu: tidak ada sumber daya lain atau kombinasi sumber daya yang akan menciptakan keunggulan kompetitif yang sama atau identik. Manajemen pengetahuan bisa bertindak sebagai sumber daya penghalang karena manajemen pengetahuan dapat menghasilkan siklus hidup inovasi yang semakin pendek dan memiliki pengaruh langsung pada bottom-line returns. Inovasi yang dihasilkan oleh manajemen pengetahuan akan menciptakan "creative destruction" sehingga organisasi akan selalu menjadi trend setter dan para follower akan kesulitan mengimitasi. Manajemen pengetahuan juga dapat menciptakan penurunan siklus waktu, menolong organisasi dari keusangan, merampingkan proses, dan memberi organisasi kemampuan 
bagaimana cara bereaksi terhadap perubahan. Dilihat dari perspektif global, manajemen pengetahuan juga menolong organisasi untuk melakukan akses global ke pengetahuan dan menolong organisasi global untuk beradaptasi dengan kondisi lokal.

\section{Konsep Pengetahuan dalam Organisasi}

Dalam berbagai kajian literatur sering memberi label pengetahuan sebagai intellectual capital yang memiliki nilai sangat kritis melebihi brand name dan asset fisik. Mencipta dan mengelola modal intelektual merupakan kunci sukses organisasi. Mendefinisikan pengetahuan secara akurat tidaklah mudah. Namun demikian banyak yang sepakat bahwa pengetahuan adalah kombinasi terorganisasi dari ide-ide, peraturan-peraturan, prosedur-prosedur, dan informasi (Bhatt, 2004). Dalam beberapa hal, pengetahuan adalah sebuah "makna" yang dibuat oleh pikiran. Tanpa makna, pengetahuan hanyalah lembam dan statis, hanya merupakan informasi yang tidak terorganisasi.Hanya melalui makna, informasi akan menjadi hidup dan menjelma sebagai pengetahuan. Informasi dan pengetahuan berbeda berdasarkan organisasi internal mereka. Informasi belum terorganisasi, sementara pengetahuan sudah terorganisasi. Pengetahuan adalah sesuatu yang humanis, aset personal yang tinggi, dan merepresentasikan kesatuan antara keahlian dan upaya dari jaringan dan aliansi. Hasil kajian menyatakan bahwa $99 \%$ dari apa yang dikerjakan manusia berbasis pada pengetahuan (Wah, 1999 dalam Smith, 2003).

Nilai dari pengetahuan akan meningkat ketika pengetahuan menjadi kunci dari tujuan dan difokuskan pada misi, cores values, dan prioritas strategis. Aset pengetahuan, seperti halnya uang dan peralatan, ada dan menjadi berharga ketika diletakkan dalam konteks strategi yang digunakan untuk mengaplikasikan pengetahuan tersebut. Nonaka dan Takeuchi (2005) menggunakan konsep tentang pengetahuan eksplisit dan pengetahuan tasit dalam upayanya mendefinisikan dimensi pengetahuan. Pengetahuan eksplisit bersifat mudah diartikulasikan, ditangkap, dan disebarkan dalam berbagai bentuk. Pengetahuan tasit sulit untuk ditangkap, dikodifikasi, diadopsi, dan didistribusi, karena individu tidak mudah mengartikulasikan pengetahuan tasit. Akar dari pengetahuan tasit secara mendalam ada dalam rutinitas kerja individu tersebut. Seorang wirausahawan yang berhasil tidak akan dengan mudah menjelaskan secara verbal mengapa ia sampai meraih kejayaan dalam bisnis. Bisa dipastikan yang diartikulasikan adalah sifat-sifat positif yang sudah diketahui awam, misalnya: kerja keras, berdoa, dukungan keluarga, berani mengambil resiko, dan lain sebagainya. Pengalaman, interaksi personal, dan -craftsmanship of experts tidak mudah diartikulasikan melalui prosedur dan resep-resep tertentu. Haldin-Herrgard 
(2004) mengumpamakan pengetahuan tasit sebagai: mampu memasak tanpa resep atau memiliki perasaan intuitif untuk membuat keputusan yang benar.

Pengetahuan tasit berisi model mental, kepercayaan, dan persuasi setiap individu dalam organisasi yang berurat berakar dalam diri mereka. Pengertian mendalam subjektif, intuisi, dan firasat termasuk dalam kategori pengetahuan tasit. Pengetahuan ini mengakar dalam tindakan dan pengalaman seperti halnya ideal, nilai-nilai, atau emosi. Setiap manusia memiliki pengetahuan tasit yang berakar sangat mendalam dalam setiap tindakan mereka, dan dalam komitmen mereka terhadap profesi tertentu, teknologi tertentu, atau aktivitas tim kerja. Dalam banyak organisasi, pengetahuan tasit jarang dibagikan atau dikomunikasikan. Akibatnya pengetahuan tasit akan hilang ketika individu pemilik pengetahuan meninggalkan organisasi. Sebab pengetahuan tasit hampit sepenuhnya tersimpan dalam diri manusia. Oleh karena itu, tidak mengherankan apabila para penganjur resourced-based berargumentasi bahwa pengetahuan tasit merupakan sumber keunggulan kompetitif (Lubit, 2003). Perlu ditambahkan, pengetahuan tasit memiliki potensi tinggi untuk menghasilkan returns ketika bekerja dalam batas-batas organisasi. Artinya, pengetahuan yang sama dalam kondisi organisasi yang berbeda akan menghasilkan output yang berbeda pula. Pengetahuan yang bersifat tasit akan memperkokoh core competence organisasi.

Ada dua dimensi dari pengetahuan tasit.Pertama, dimensi teknik, yang meliputi jenis-jenis ketrampilan personal yang bersifat informal atau seni yang sering diberi label sebagai “know-how”. Kedua, dimensi kognitif, yang berisi kepercayaan, nilai, skema, dan model mental. Karena beberapa pengetahuan bersifat tasit, maka peran pengetahuan tasit sebagai sumber daya untuk membangun keunggulan kompetitif semakin mendapat posisi terhormat. Hal itu akan terjadi apabila pengetahuan tasit individu difasilitasi oleh organisasi untuk berinteraksi dengan individu dan membuat mereka sensitif terhadap stimuli lingkungan sehingga pengetahuan individu diperkuat dan diinternalisasi untuk berkontribusi pada organisasi berbasis pengetahuan (Nonaka, 1999 dalam Bhatt, 2003).

Selanjutnya, pengetahuan eksplisit adalah pengetahuan yang dapat dikodifikasikan. Pengetahuan ini mudah diekspresikan dalam kata-kata dan angka, dalam bentuk data, formula ilmiah, spesifikasi, dan manual. Pengetahuan eksplisit dapat bermigrasi dalam komunitas bisnis dan dapat diakses untuk seluruh organisasi dengan tanpa mempertimbangkan aktivitas kerja-sama mereka. Pengetahuan ini dikodifikasi dan disimpan dalam basis data yang dapat diakses dan digunakan secara mudaholeh siapapun dalam organisasi (Vivi, 2004). Ada tiga tipe pengetahuan eksplisit yang ada dalam organisasi: pengetahuan kognitif, sistem ketrampilan tingkat tinggi, dan sistem pemahaman. Pengetahuan kognitif, juga diberi label sebagai “ know- 
what", adalah basic mastery dari disiplin seorang profesional yang didapat dari pelatihan dan sertifikasi.

Selanjutnya ketrampilan tingkat tinggi atau "know-how” merujuk pada kemampuan mengaplikasikan aturan-aturan dari suatu disiplin profesional pada masalah riil dunia yang kompleks. Sedangkan sistem pemahaman, juga disebut sebagai "know-why", adalah suatu pemahaman yang mendalam dari suatu jejaring relasi sebab-akibat yang mendasari suatu disiplin. Nonaka dan Takeuchi (2004) membangun sebuah model dinamis tentang kreasi pengetahuan. Dalam model tersebut, mereka menjelaskan sebuah asumsi kritis bahwa pengetahuan manusia dikreasi dan diperluas melalui interaksi sosial diantara pengetahuan tasit dan eksplisit. Dengan demikian, knowledge management dapat dipandang sebagai kreasi keunggulan kompetitif berkelanjutan melalui pembelajaran yang kontinyu. Meso dan Smith (2004) menyatakan bahwa: "Since the value of the intellect increases markedly as one moves up the intellectual scale from cognitive knowledge through advanced skills and systems thingking to self-motivated creativity enhancing intellectual capital within the firm assures the sustainable competitive advantage of the firm".

\section{Konsep Kompetensi Profesi Sistem Informasi}

Kompetensi merupakan perpaduan dari pengetahuan, ketrampilan, nilai dan sikap yang direfleksikan dalam kebiasaan berpikir dan bertindak. McAshan (2008) mengemukaan bahwa kompetensi: “...is a knowledge, skills, and abilities or capabilities that a person achieves, which become part of his or her being to the exent he or she can satisfactory perform particular cognitive, affective, and psychomotor behaviors. Selanjutnya Gordon (2005) menjelaskan beberapa aspek atau ranah yang terkandung dalam konsep kompetensi sebagai berikut:

1. Pengetahuan (knowledge): yaitu kesadaran dalam bidang kognitif misalnya seorang pengajar STMIK raharja mengetahui cara melakukan identifikasi kebutuhan belajar, dan bagaimana melakukan pembelajaran terhadap mahasiswa sesuai dengan kebutuhannya.

2. Pemahaman (understanding): yaitu kedalaman kognitif, dan afektif yang dimiliki individu. Misalnya seorang pengajar STMIK Raharja yang akan melaksanakan pembelajaran harus memiliki pemahaman yang baik tentang karakteristik dan kondisi mahasiswa, agar dapat melaksanakan pembelajaran secara efektif dan efisien.

3. Kemampuan (skill): adalah sesuatu yang dimiliki individu untuk melakukan tugas atau pekerjaan yang dibebankan kepadanya. Misalnya kemampuan 
pengajar STMIK Raharja dalam memilih dan membuat alat peraga untuk memberi kemudahan belajar mahasiswa.

4. Nilai (value): adalah suatu standar perilaku yang telah diyakini dan secara psikologis telah menyatu dalam diri seseorang. Misalnya standar perilaku pengajar STMIK Raharja dalam pembelajaran (kejujuran, keterbukaan, demokratis dan lain sebagainya).

5. Sikap (attitude): yaitu perasaan (senang-tidak senang, suka-tidak suka) atau reaksi terhadap suatu rangsangan yang datang dari luar. Misalnya reaksi terhadap krisis ekonomi, perasaan terhadap kenaikan gaji, dan sebagainya.

6. Minat (interest): adalah kecenderungan seseorang untuk melakukan sesuatu perbuatan. Misalnya minat untuk mempelajari atau melakukan sesuatu.

Berdasarkan aspek tersebut maka dapat dikatakan bahwa kompetensi adalah halhal yang melekat kepada seorang individu yang memungkinkan dia melakukan suatu pekerjaan tertentu. Model kompetensi yang banyak menjadi rujukan oleh para praktisi di bidang manajemen sumber daya manusia berbasis kompetensi (competence based human resource management) adalah model kompetensi yang disusun oleh Lyle M. Spencer dan Signe M. Spencer (1993). Hanya saja, model kompetensi tersebut hanya memuat profil kompetensi generik, atau dikenal juga dengan istilah soft competence. Lyle M. Spencer dan Signe M. Spencer menggunakan dua istilah yaitu kompetensi generik ( generic competence) dan technical know-how yang sering dikenal dengan istilah hard competence.

Mereka menyusun 26 (dua puluh enam) kompetensi generik yang dianggap mampu membawa kinerja yang superior untuk karyawan dan pimpinan, dan dampaknya tentu saja ke organisasi. Mereka mendefinisikan technical know-how sebagai suatu keahlian teknis di bidang tertentu, termasuk di bidang sistem informasi. Tetapi mereka berargumen bahwa technical know-how semata tidak akan membawa keunggulan superior untuk karyawan dan pimpinan. Technical know-how tersebut harus dilengkapi dengan apa yang mereka sebut dengan kompetensi generik, yang merupakan gabungan dari kemampuan berpikir, kemampuan berhubungan antar manusia, memahami organisasi, dorongan berprestasi, dan sebagainya. Setiap kompetensi generik memiliki tingkat (competence level), biasanya menggunakan skala dari 1 sampai 5 atau 7. Beberapa kompetensi dari 26 (dua puluh enam) kompetensi generik tersebut dapat dilihat pada Tabel 1 yang disadur dari buku mereka.

Melengkapi konsep Lyle M. Spencer dan M. Spencer, maka Antoinette D. Lucia dan Richard Lepsinger mengemukakan model kompetensi yang lain, yang fokusnya lebih kepada proses atau tahapan menyusun profil kompetensi di dalam sebuah organisasi. Mereka sudah mengintegrasikan model kompetensi dengan sistem 
manajemen sumber daya manusia, meliputi rekrutmen dan seleksi, pengembangan sumber daya manusia, penilaian karya dan kinerja, serta suksesi jabatan di dalam organisasi. Mereka juga menuliskan 5 (lima) langkah rinci dalam menyusun profil kompetensi, yaitu (1) persiapan, (2) membangun model dari awal, (3) finalisasi dan validasi,(4) mengintegrasikannya ke sistem manajemen sumber daya manusia, serta (5) mengkomunikasikannya dengan berbagai pihak di dalam organisasi. Masingmasing langkah tersebut juga memiliki sub-langkah tersendiri (Lucia, 2004).

Di pihak lain, sistem informasi adalah sebuah disiplin baru yang belum sepenuhnya mapan, seperti matematika dan ekonomi. Karena sebelum membahas tentang profil kompetensi profesi sistem informasi, pengetahuan dan pemahaman tentang ruang lingkup kajian bidang sistem informasi sangat diperlukan. Pengetahuan ini akan memberikan perspektif yang lebih luas dalam memandang hubungan antara disiplin sistem informasi dengan disiplin ilmu yang lain.

Tabel 1: Beberapa kompetensi generik oleh Lyle M. Spencer dan Signe M. Spencer (2004).

\begin{tabular}{|c|c|}
\hline Generic Competences & The ablity to ... \\
\hline Achievement orientation & $\begin{array}{l}\text { Concern for working well or for competing against a standard or } \\
\text { excellent. }\end{array}$ \\
\hline $\begin{array}{l}\text { Concern for order, quality, and } \\
\text { accuracy }\end{array}$ & $\begin{array}{l}\text { Reduce uncertaintiy in the surrounding environment, by monitoring } \\
\text { and checking work or information, clarify roles and functions, etc. }\end{array}$ \\
\hline Initiative & $\begin{array}{c}\text { Take action, doing more than is required or expected in the job, doing } \\
\text { things that no one has requested which will improve or enchance job } \\
\text { results. }\end{array}$ \\
\hline Information seeking & $\begin{array}{l}\text { Know more about things, people, or issues, making an effort to get } \\
\text { more information, not accepting situations 'at face value' }\end{array}$ \\
\hline Interpersonal understanding & $\begin{array}{c}\text { Understand other people, hear accurately and understanding the } \\
\text { unspoken or partly expressed thoughts, feelings, and concerns of } \\
\text { others. }\end{array}$ \\
\hline Customer service orientation & To help and serve others, discover and meet their needs. \\
\hline Inpact and influence & $\begin{array}{l}\text { Persuade, convince, influence, or impress other, in order to get them } \\
\text { to support the speaker's agenda, the desire to have a specific impact } \\
\text { or effect on others. }\end{array}$ \\
\hline Organizational awareness & $\begin{array}{l}\text { Understand the power relationship in his or her own organization or } \\
\text { other organizations, indentify who are the real decision makers, who } \\
\text { can influent them, etc. }\end{array}$ \\
\hline Relationship building & $\begin{array}{c}\text { Build or maintain friendly, warm relationships, at networks of } \\
\text { contacts with people who are, or might someday be, useful in } \\
\text { achieving work-related goals. }\end{array}$ \\
\hline
\end{tabular}

Perkembangan sistem informasi telah mengubah pola pikir manusia yang merupakan respon terhadap kemasan informasi. Contoh perubahan pola pikir tersebut adalah lahirnya e-mail yang mengubah cara berkirim surat, $e$-business atau e-commerce 
yang telah mengubah cara berbisnis dengan segala turunannya, termasuk e-cash atau e-money. E-government telah membuka babak baru pengelolaan pemerintahan dan mekanisme hubungan antara pemerintah, dunia bisnis, dan masyarakat. $E$ learning menawarkan cakrawala baru proses belajar-mengajar. Perubahanperubahan tersebut terus berlangsung dan dalam beberapa bidang sudah mulai mapan, terutama di Negara-negara maju.

Oleh karena itu, di bidang sistem informasi, upaya merumuskan kompetensi juga dilakukan oleh berbagai pihak untuk mengimbangi perkembangan teknologi yang begitu pesat. Upaya tersebut telah dilakukan oleh Feeny dan Wilcock. Mereka mengungkapkan bahwa ada 9 kompetensi yang terdapat pada bidang profesi sistem informasi (Ward, 2002). Kesembilan kompetensi tersebut dapat dilihat pada Tabel 2 dibawah ini. Jika dianalisis lebih lanjut, maka 9 kompetensi yang disusun oleh Feeny dan Willcock sudah memadukan dua jenis kompetensi, yaitu hard competences dan soft competences.

Tabel 2: Profil kompetensi di bidang profesi sistem informasi oleh Feeny and Willcock (2002).

\begin{tabular}{|c|c|}
\hline IS Competences & The ablity to ... \\
\hline $\begin{array}{l}\text { Information Systems } \\
\text { Leandership }\end{array}$ & Integrating Information Systems effort wih business purpose and activity. \\
\hline Business systems thinking & Envisioning the business processes that technology nakes possible. \\
\hline Relationships building & Getting the business contructively engaged in Information Systems issues \\
\hline Architecture planning & $\begin{array}{c}\text { Creating a coherent blueprint for a technical platform that responds to } \\
\text { current and future business. }\end{array}$ \\
\hline Making technology work & Rapidly achieving technical progress by ones means of another. \\
\hline Informed buying & $\begin{array}{l}\text { Managing the IS/IT sourcing strategy that meets the interests of the } \\
\text { business. }\end{array}$ \\
\hline Contract facilitation & $\begin{array}{c}\text { Ensuring the success of existing contract for Information Systems } \\
\text { services. }\end{array}$ \\
\hline Contract monitoring & Protecting the business contractual position, current and future. \\
\hline Vendor development & $\begin{array}{c}\text { Identifying the potential added value of Information Systems service } \\
\text { suppliers. }\end{array}$ \\
\hline
\end{tabular}

Pihak lain yang melakukan penelitian untuk kompetensi di bidang sistem informasi adalah Marchand, et al (2003). Mereka mengungkapkan ada 6 kelompok kompetensi di bidang sistem informasi. Konsep yang diungkapkan oleh Marchand ini ternyata mendapatkan sambutan yang sangat luas di berbagai kalangan, dan Marchand juga mengeluarkan alat bantu untuk evaluasi yang digambarkan dalam 
bentuk diagram sarang laba-laba. Keenam kelompok kompetensi dan rinciannya sebanyak 26 kompetensi di bidang sistem informasi dapat dilihat pada Tabel 3 dan Tabel 4 berikut ini.

Tabel 3: Profil kompetensi di bidang profesi sistem informasi oleh Marchand et al (2003).

\begin{tabular}{|c|c|c|}
\hline $\begin{array}{l}\text { Hard competency Area of } \\
\text { Information Systems }\end{array}$ & The ability to .... & Competencies (detail) \\
\hline Strategy. & $\begin{array}{l}\text { Identify and evaluate the implications } \\
\text { of Information Systems based } \\
\text { opportunities as an integral part of } \\
\text { business strategy formulation and } \\
\text { define the role of Information System } \\
\text { in the organization. }\end{array}$ & $\begin{array}{l}\text { Business strategy. } \\
\text { Technology innovation. } \\
\text { Investment criteria. } \\
\text { Information governance. }\end{array}$ \\
\hline $\begin{array}{l}\text { Define the information } \\
\text { system contribution. }\end{array}$ & $\begin{array}{l}\text { Translate the business strategy into } \\
\text { process, information, and system } \\
\text { investment and change plans that } \\
\text { match the business priorities. }\end{array}$ & $\begin{array}{c}\text { Prioritization. } \\
\text { Information System strategy } \\
\text { alignment. } \\
\text { Business process design. } \\
\text { Business performance } \\
\text { improvement. }\end{array}$ \\
\hline $\begin{array}{l}\text { Define the information } \\
\text { technology capability. }\end{array}$ & $\begin{array}{l}\text { Translate the business strategy into } \\
\text { long term information architectures, } \\
\text { technology infrastructure and } \\
\text { resourcing plant that enable the } \\
\text { implementation of the strategy. }\end{array}$ & $\begin{array}{l}\text { Infrastructure development. } \\
\text { Technology analysis. } \\
\text { Sourcing strategies. }\end{array}$ \\
\hline Exploitation. & $\begin{array}{l}\text { Maximized the benefits realized from } \\
\text { the implementation of Information } \\
\text { System investments throught effective } \\
\text { use of information, applications and IT }\end{array}$ & $\begin{array}{l}\text { Benefits planning. } \\
\text { Benefits delivery. } \\
\text { Managing change. }\end{array}$ \\
\hline
\end{tabular}

\begin{tabular}{|c|c|c|}
\hline & services. & \\
\hline Deliver solution. & Deploy resources to develop, & Application development. \\
& implement, and operate Information & Service management. \\
& Systems business solutions that exploit & Information asset \\
& the capabilities of the technology. & management. \\
& & Implementation \\
& & management. \\
& & Apply technology. \\
\hline Supply. & Create and maintain an appropriate & Supplier relationships \\
& and adaptable information, & Technology standards. \\
& technology, and application supply & Technology acquisition. \\
& chain and resource capacity. & Asset and cost management. \\
\hline
\end{tabular}

Tabel 4. Profil kompetensi lebih rinci di bidang profesi sistem informasi oleh Marchand et al (2003). 
ISSN: 1978 - 8282

\begin{tabular}{|c|c|}
\hline $\begin{array}{l}\text { Hard competencies for } \\
\text { Information Systems }\end{array}$ & The ablity to ... \\
\hline Business strategy. & $\begin{array}{c}\text { Ensure that business strategy formulation identifies the most advantageous } \\
\text { uses of information, system, and technology. }\end{array}$ \\
\hline Technology innovation. & $\begin{array}{c}\text { Incorporate the potential of new and emerging technologies in long-run } \\
\text { business development. }\end{array}$ \\
\hline Investment criteria. & $\begin{array}{c}\text { Established appropriate criteria for decision making on investment in } \\
\text { information, system, and technology. }\end{array}$ \\
\hline Information & $\begin{array}{l}\text { Define information management policies for the organization and the roles } \\
\text { and responsibilities of general management and the Information Systems } \\
\text { function. }\end{array}$ \\
\hline Priori & $\begin{array}{l}\text { Ensure that the portfolio of investmen in application and technology } \\
\text { produce the maximum return from resource available. }\end{array}$ \\
\hline IS strate & $\begin{array}{c}\text { Ensure that Information Systems development plans are integrated with } \\
\text { organizational and functional strategic plans. }\end{array}$ \\
\hline Business & $\begin{array}{l}\text { Determine how In formation System can deliver 'best partice' in the } \\
\text { operational processes of organizational activities. }\end{array}$ \\
\hline $\begin{array}{l}\text { Business performance } \\
\text { improvements. }\end{array}$ & $\begin{array}{l}\text { Indentify the knowledge and information needed to deliver strategic } \\
\text { objectives through improved management processes. }\end{array}$ \\
\hline $\begin{array}{l}\text { System and process } \\
\text { innovation. }\end{array}$ & $\begin{array}{l}\text { Carry out relevant research and development into how Information Systems } \\
\text { can be used to create new ways of conducting business and new products }\end{array}$ \\
\hline $\begin{array}{l}\text { Infrastructure } \\
\text { development. }\end{array}$ & $\begin{array}{l}\text { Define and design information, application, and technology architectures } \\
\text { and organization structures and processes to manage the resources. }\end{array}$ \\
\hline Technology analysis. & $\begin{array}{l}\text { Understand technology developments and make appropriate } \\
\text { recommendations for organizational acquisition of technology and } \\
\text { associated resources. }\end{array}$ \\
\hline Sourcing strategies. & $\begin{array}{c}\text { Establish criteria and processes to evaluate supply options and contracts } \\
\text { with suppliers. }\end{array}$ \\
\hline Benefits planning. & $\begin{array}{l}\begin{array}{c}\text { Explicity identify and planto realize the benefits from Informations System } \\
\text { investments. }\end{array}\end{array}$ \\
\hline Benifts delivery & $\begin{array}{c}\text { Monitor, measure, and evaluate the benefits derived from Information } \\
\text { System investment and use. }\end{array}$ \\
\hline Managing change. & $\begin{array}{l}\text { Make the business and organizational changes required to macimize } \\
\text { without detrimental impacts on stakeholders. }\end{array}$ \\
\hline
\end{tabular}

\begin{tabular}{|c|c|}
\hline Application development. & $\begin{array}{c}\text { Develop, acquire, and implement information, system, and technology } \\
\text { solutions that satisfy business needs. }\end{array}$ \\
\hline Service $m$ & $\begin{array}{l}\text { Define service arrangements and performance criteria to match the } \\
\text { business requirements, including project management. }\end{array}$ \\
\hline $\begin{array}{l}\text { Information asset } \\
\text { management. }\end{array}$ & $\begin{array}{l}\text { Establish and operate processes that ensure data, information, and } \\
\text { knowledge management activities meet organizational needs and satisfy } \\
\text { corporate policies. }\end{array}$ \\
\hline $\begin{array}{r}\text { Implem } \\
\text { mana }\end{array}$ & $\begin{array}{l}\text { Ensure that new processes and ways of working are designed and } \\
\text { implemented effectively in conjuction with new technology. }\end{array}$ \\
\hline Apply tec & $\begin{array}{r}\text { Deploynew/changed technology in the mos } \\
\text { application bene }\end{array}$ \\
\hline $\begin{array}{r}\text { Business } \\
\text { se }\end{array}$ & $\begin{array}{l}\text { Provide effective recovery, contingency and security processes to prevent } \\
\text { risk of business failure. }\end{array}$ \\
\hline Supplier & Manage contracts and develop value-added relationships with suppliers. \\
\hline Technolo & $\begin{array}{l}\text { Develop and maintain appropriate standards, } \\
\text { procedures for the use of Information System an }\end{array}$ \\
\hline Technolog & $\begin{array}{l}\text { Develop and apply procurement policies and procedures for the } \\
\text { organizational acquiation of infrastructure components and specialist } \\
\text { technologies/services. }\end{array}$ \\
\hline $\begin{array}{l}\text { Asset and cost } \\
\text { management. }\end{array}$ & $\begin{array}{l}\text { Ensure technology, information and application assets are effectively } \\
\text { maintained and costs of acquisition and ownership are understood and } \\
\text { managed. }\end{array}$ \\
\hline $\begin{array}{l}\text { Information System staff } \\
\text { development. }\end{array}$ & $\begin{array}{l}\text { Recruit, train, and deploy appropriate staff and ensure technical, business } \\
\text { and personal skills meer the needs of the organization. }\end{array}$ \\
\hline
\end{tabular}

Vol.5 No.1 - September 2011 
Upaya meneliti kompetensi di bidang profesi sistem informasi juga dilakukan oleh Genevieve Bassellier dan Izak Benbasat (2004). Tetapi mereka membatasi penelitian mereka hanya untuk kompetensi bidang bisnis untuk profesional teknologi informasi. Mereka menyimpulkan bahwa nuansa pekerjaan pada profesional teknologi informasi sudah berubah, di mana berinteraksi dengan berbagai pihak dari bidang fungsional lainnya sudah menjadi bagian dari pekerjaan mereka. Para profesional di bidang sistem informasi sudah harus bekerja sama dengan para profesional di bidang bisnis di manajemen untuk menciptakan sesuatu yang bermanfaat.

Mereka mengungkapkan ada 7 kompetensi di bidang bisnis yang perlu juga dimiliki oleh para profesional di bidang sistem informasi dalam menghadapi pekerjaan sekarang, yaitu (1) pemahaman mengenai organisasi,(2) unit dalam organisasi, (3) tanggung jawab dalam organisasi, (4) integrasi bisnis dan sistem informasi,(5) jejaring pengetahuan, (6) komunikasi interpersonal, dan (7) kepemimpinan. Terobosan terakhir mengenai kompetensi dan sistem informasi dilakukan oleh Robert Kaplan dan David Norton (2004), keduanya dikenal sebagai pencetus konsep balanced scorecard. Konsep balanced scorecard sendiri sudah mengalami 3 (tiga) generasi.

Balanced scorecard generasi pertama lebih memfokuskan kepada strategic measurements untuk kinerja organisasi dalam bentuk empat perspektif, dan tidak semata perspektif keuangan yang bisa dilakukan saat itu. Sedangkan generasi kedua merupakan pengembangan lanjutan, dimana balanced scorecard sudah mulai dipergunakan sebagai alat untuk memetakan strategi dalam bentu hubungan sebabakibat, tidak hanya strategic measurements semata. Balanced scorecard generasi ketiga mulai membicarakan aset yang berwujud di dalam organisasi, serta bagaimana memanfaatkannya untuk mencapai kinerja superior. Aset tak berwujud itu adalah (1) human capital atau kompetensi, (2) information capital atau informasi, serta (3) organization capital atau budaya organisasi. Mereka memperkenalkan konsep intangible assets readiness measurements yang diintegrasikan dengan peta strategi perusahaan, di mana kita bisa mengintegrasikan kompetensi yang dibutuhkan oleh bidang sistem informasi dengan baik dan terukur baik validitas maupun reliabilitasnya.

STMIK Raharja yang merupakan institusi pendidikan tinggi khusus dalam bidang teknologi informasi beserta turunannya harus memiliki 5 karakteristik yang melekat pada pribadi raharja:

1. Sifat pelayanan (the nature of the service act). Layanan yang dihasilkan oleh lembaga pendidikan lebih mengarah kepada hal yang bersifat intangiblepeople based - daripada hal-hal yang bersifat fisik-equipment based. Dalam proses pelayanan juga melibatkan aksi-aksi yang intangible.

2. Hubungan dengan konsumen (the relationship with customer). Layanan pendidikan melibatkan hubungan dengan konsumen bersifat formal serta 
dilakukan terus-menerus (continuous). Mahasiswa sebagai konsumen mempunyai hubungan keanggotaan dengan pihak kampus. Hal ini memungkinkan terbentuknya loyalitas yang tinggi (pihak mahasiswa) dan peningkatan kualitas layanan terhadap konsumen (pihak kampus).

3. Tingkat kustomisasi dan penilaian pelayanan (the level of customization and judgement in service delivery). Tingkat kustomisasi pendidikan sangat bervariasi. Tutorial dengan peserta sedikit atau bimbingan individual akan lebih mudah dikustomisasi daripada pendidikan dengan banyak peserta. Semakin terkustomisasinya layanan yang ditawarkan menjadikan konsumen memiliki tingkat pengharapan yang tinggi terhadap kualitas layanan, terutama terkait dengan kualitas staf pengajar. Jika demikian, masalah yang akan muncul adalah kemungkinan adanya hubungan antara kualitas dan tingkat keragaman layanan. Semakin beragam layanan yang ditawarkan, kemungkinan menurunnya kualitas semakin tinggi.

4. Sifat permintaan relative terhadap penawaran (the nature of demand relative to supply). Dalam bidang jasa, terdapat widespread demand (seperti tenaga listrik) dan narrow demand (seperti kamar hotel). Tingkat penawaran untuk memenuhi permintaan yang berfluktuasi sangat berbeda. Peningkatan permintaan tenaga listrik akan lebih mudah dan lebih cepat diatasi dengan meningkatkan kapasitas produksi, jika masih tersedia, dibandingkan dengan peningkatan permintaan terhadap akomodasi hotel. Dalam dunia pendidikan, permintaan terkait dengan narrow demand. Dengan memikian penawaran akan sulit dikelola, karena terkait dengan keterbatasan tenaga pengajar dan program studi yang ditawarkan.

5. Metode pelayanan (the method of service delivery). Metode pelayanan bergantung pada outlet layanan (single atau multiple) dan sifat interaksi antara konsumen dengan penyedia jasa. Konsumen harus datang ke penyedia jasa dan sebaliknya. Dalam jasa pendidikan, umumnya lembaga pendidikan mensyaratkan konsumen yang datang ke kampus. Namun seiring dengan perkembangan teknologi, memungkinkan dilakukannya distance learning.

Satu hal yang harus ditekankan adalah bahwa strategi bisnis harus sejalan (well-aligned) dengan strategi sistem informasi. Dalam konteks ini, kesejalanan (alignment) antara manajemen puncak dan menajemen sistem informasi menjadi syarat utama. Henderson dan Venkatraman (1999) mengusulkan empat perspektif strategic alignment terkait dengan pemanfaatan sistem informasi di sebuah organisasi: (1) strategy execution; (2) technology transformation; (3) competitive potential; dan (4) service level. Perspektif pertama dan kedua mengasumsikan strategi bisnis 
sebagai faktor pendorong, sedang perpektif ketiga dan keempat mengasumsikan strategi sistem informasi sebagai pendorong. Perspektif ini berasal dari asumsi hubungan yang berbeda antara strategi bisnis dengan infrastruktur sistem informasi.

Meskipun banyak perubahan yang bisa dilakukan dengan bantuan sistem informasi, namun demikian tantangan atau hambatan harus diatasi untuk menciptakan kondisi yang kondusif untuk optimalisasi pemanfaatan sistem informasi di perguruan tinggi dalam menyusun profil kompetensi profesional sistem informasi yang diharapkan. Optimalisasi pemanfaatan sistem informasi juga memerlukan perubahan pola pikir dari deduktif menjadi induktif, dan kesejalanan antara manajemen puncak (strategi bisnis) dan manajemen sistem informasi (strategi sistem informasi). Hal ini juga berarti bahwa investasi di bidang sistem informasi harus diikuti dengan langkah-langkah perbaikan dan penyesuaian kualitas manusia, proses, dan organisasi terutama dalam menyusun profil kompetensi yang diharapkan.

\section{KESIMPULAN}

Pada masa sekarang, ekonomi berbasis pengetahuan adalah sebuah keniscayaan. Manajemen pengetahuan telah muncul sebagai tantangan signifikan terhadap manajemen dan organisasi. Para praktisi dan akademisi semakin yakin bahwa pengetahuan merupakan sumber daya yang paling ampuh dalam memperoleh keunggulan kompetitif yang langgeng. Oleh karena itu, memiliki kemampuan untuk mengelola pengetahuan akan menjadi pekerjaan utama dari setiap pekerjaan. Dalam ekonomi yang berbasis 'otak' daripada 'otot', asset intelektual adalah fokusnya.

Knowledge management dapat dimanfaatkan untuk membuat proses yang sistematik dan integral dalam mengkoordinasikan seluruh aktivitas organisasi dalam membuat, menyimpan, membagi, menghubungkan, mengembangkan, dan menyebarkan pengetahuan oleh individu dan kelompok dengan tujuan untuk mengejar tujuan organisasi, yaitu: kesejahteraan organisasi. Jadi, pada masa kini organisasi adalah suatu berkas aset pengetahuan. Pengetahuan eksplisit bersifat mudah diartikulasikan, ditangkap, dan disebarkan dalam berbagai bentuk. Pengetahuan tasit sulit untuk ditangkap, dikodifikasi, diadopsi, dan didistribusi, karena individu tidak bisa secara mudah mengartikulasikan pengetahuan tasit.

Ada dua jenis kompetensi, yaitu hard competence yang sering juga disebut dengan technical know-how, serta kompetensi generik yang sering juga disebut dengan soft-competence. Keduanya diperlukan untuk mencapai keunggulan superior dalam kinerja, baik individu, maupun organisasi. Keduanya harus disusun dalam bentuk tingkat kompetensi, dan nanti direlasikan dengan job requirements untuk bidang sistem informasi. Dengan demikian, sebaiknya dalam penyusun profil 
kompetensi untuk departemen atau bagian sistem informasi di dalam organisasi, dua jenis kompetensi ini dimasukkan, dan tidak hanya memasukkan technical knowhow atau hard-competence semata, setelah itu dilakukan pemeringkatan kompetensi dan direlasikan dengan job requirements.

Kompetensi mengenai bisnis dan manajemen sudah harus dimiliki oleh para profesional di bidang sistem informasi. Dengan demikian, hard-competence atau technical know-how untuk profesional sistem informasi tidak hanya kompetensi teknis di bidang teknologi informasi atau komputer semata, melainkan juga sebagian bidang bisnis dan manajemen, dan integrasi keduanya. Dengan demikian, dalam menyusun profil kompetensi untuk departemen atau bagian sistem infromasi di dalam organisasi, sebaiknya kompetensi di bidang bisnis dan menajemen serta integrasi keduanya perlu dimasukkan. Penyusunan profil kompetensi tersebut tetap harus merujuk kepada strategi organisasi dan untuk itu dibutuhkan alat bantu untuk mengintegrasikan strategi organisasi dengan kompetensi di bidang sistem informasi, sesuai kebutuhan organisasi. Balanced scorecard generasi ketiga dapat dipergunakan sebagai alat bantu untuk melakukan integrasi tersebut.

Tetapi walaupun demikian, perlu dilakukan suatu kajian yang lebih mendalam lagi mengenai bagaimana penerapan kedua hal di atas untuk kondisi di Indonesia. Apakah perusahaan yang berkinerja tinggi, di mana sistem informasi berkontribusi besar untuk mendongkrak kinerja tersebut, sudah menerapkan kedua hal di atas ? Perlukah 26 kompetensi generik versi Spencer dan Spencer diterapkan pada profesi sistem informasi atau hanya sebagian saja? Ini adalah suatu obyek kajian yang menarik untuk penelitian kompetensi untuk profesi sistem informasi di Indonesia.

\section{DAFTAR PUSTAKA}

1. Bassel, G. I. Benbasat, (2004), Business Competence of Information Technology Professional: Conceptual development and Influence of ITBusiness Partnerships, dalam : MIS Quarterly Volume 28, Number 4, December 2004.

2. Bhatt, Ganesh D, (2000), Organizing Knowledge in the Knowledge development Cycle, Journal of Knowledge Management, Vol.4, No.1.

3. Civi, Emin, (2000), Knowledge Management as a competitive asset: a Review, Marketing Intelligence and Planning, Vol.1. No.4.

4. Henderson, J.C, Venkatraman, N. (1999), Strategic Alignment: Leveraging Information Technology for Transformating Organizations, IBM Systems Journal, Vol.5 No.38.

5. Kaplan, R. S., D. P. Norton, (2004), Strategy Maps, Harvard Business School Press, Massachusetts. 
6. Lang, Josephine Chinying, (2001), Managing in Knowledge-Based Competition, Journal of Organizational Change Management, Vol.14, No.6.

7. Lubit, Roy, (2001), Tacit Knowledge and Knowledge Management: the Key to Sustainable Competitive advantage, Organizational Dynamics, Vol.29, No.4.

8. Lucia, A, D., R. Lepsinger, (1999), The Art and Science of Competency Models: Pinpointing Critical Succes Factors in Organizations, JosseyBass Peiffer, New York.

9. Nonaka, I. Takeuchi, H. (1995), the Knowledge Creating Company: How Japanese Companies Create the Dynamics of Innovation. New York: Oxford University Press.

10. Sharp, Duane, (2003), Knowledge Management Today: Challenges and Opportunities. Information Systems Management, New York.

11. Spencer, L. M., S. M. Spencer, (1993), Competence at Work: Models for Superior Performance, John Wiley \& Sons, New York.

12. Ward, J., J. Peppard, (2002), Strategic Planning for Information Systems,

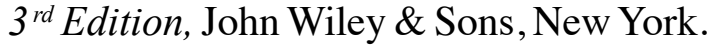

